Annals of International Medical and Dental Research

E-ISSN: 2395-2822 | P-ISSN: 2395-2814

Vol-8, Issue-1 | January-February 2022

DOI: $10.53339 /$ aimdr.2022.8.1.28

Page no- 205-211 | Section- Research Article (ENT)

\title{
Comparative Study of Outcome of Tympanoplasty by Postauricular and Permeatal Approach
}

\author{
Mushfiqur Rahman ${ }^{1 *}$, Kazi Atikuzzaman²
}

\begin{abstract}
${ }^{1}$ Assistant Professor, Department of ENT Head Neck Surgery, Enam Medical College Hospital, Dhaka, Bangladesh.

Email: shishircomch12@yahoo.com

Orcid ID: 0000-0002-6556-1859.

2Professor, Department of ENT Head Neck Surgery, Enam Medical College Hospital, Dhaka, Bangladesh.

Email: dratikmmc@yahoo.com

Orcid ID: 0000-0002-4406-3308.
\end{abstract}

*Corresponding author

Received: 13 October 2021

Revised: 25 November 2021

Accepted: 02 December 2021

Published: 22 December 2021

\begin{abstract}
Background: As from time of residency, tympanoplasty is the most common operation performed by an otolaryngologist. Because of the continuing efforts of otologists all around the world to produce the maximum surgical outcome, significant improvements in this surgical method have developed during the middle ages. Objective: The aim of the study was to compare the outcome of Tympanoplasty in Postauricular and Permeatal Approach. Methods: A total of 74 patients between the age group 15 to 44 years who were attending the ENT OPD, suffering from Chronic Suppurative Otitis Media (CSOM) were selected on the basis of type of perforation and their workup was done to assess the candidature for tympanoplasty. Comparative analysis between the two groups were done based on analysis using SPSS 24 software version. The level of significance was set to $5 \%(p<0.05)$. Results: A total of 74 patients were included in the study and the overall graft take was $76.92 \%$ in cases of Permeatal technique as compared to $91.66 \%$ in the case of postaural underlay technique. The complication of postaural approach higher than Permeatal approach. There was a difference in hearing improvement with majority of the cases improving to the range of 10-22 $\mathrm{dB}$ in Permeatal technique compared to $08-18 \mathrm{~dB}$ in Postaural Underlay technique. Conclusion: In terms of complications and hearing improvement, the Permeatal method outperforms the Postauricular Approach, however the graft takes a higher percentage in the Postauricular Approach than the Permeatal Approach.
\end{abstract}

Keywords:- Tympanoplasty; Postauricular; Permeatal; membrane healing.

\section{INTRODUCTION}

Tympanoplasty is one of the most common surgery performed in the Department of Otolaryngology. During the last hundred years various modifications in the surgical technique have been introduced because of continued efforts made by otologists all over the world to achieve the best surgical outcome. With the advent of microscope, the traditional techniques have been modified to minimal invasive surgery achieving better results and less complication rate. Term tympanoplasty was first used in 1953 by Wullstein to describe surgical techniques for reconstruction of the middle ear hearing mechanism that had been impaired or destroyed by chronic ear disease. [1] Wullstein classified Tympanoplasty into five different types, originally described by in 
Annals of International Medical and Dental Research

E-ISSN: 2395-2822 | P-ISSN: 2395-2814

Vol-8, Issue-1 | January-February 2022

DOI: $10.53339 /$ aimdr.2022.8.1.28

Page no- 205-211 | Section- Research Article (ENT)

1956.[2] Type 1 involves repair of the tympanic membrane alone, when the middle ear is normal. A type 1 tympanoplasty is synonymous to myringoplasty. Type 2 involves repair of the tympanic membrane and middle ear in spite of slight defects in the middle ear ossicles. Type 3 involves removal of ossicles and epitympanum when there are large defects of the malleus and incus. The tympanic membrane is repaired and directly connected to the head of the stapes. Type 4 describes a repair when the stapes foot plate is movable, but the crura are missing. The resulting middle ear will only consist of the eustachian tube and hypotympanum. Type 5 is a repair involving a fixed stapes footplate. The surgical procedure tympanoplasty has achieved a state of art over the years. Various techniques have been attempted in order to achieve better results with improved hearing. These include the overlay tympanoplasty, [3] the underlay tympanoplasty, [4] over underlay tympanoplasty,[5] Gelfilm tympanoplasty,[6] Crown cork tympanoplasty, [] Swinging door tympanoplasty, [] laser assisted spot welding techniques,[9] microclip techniques and others like the fascial pegging, $[10,11]$ annular wedge tympanoplasty,[12] loop tympanoplasty, [13] paper patching, lobule fat graft and the selfstabilizing tympanic membrane patchers.[14] Post auricular approach: In 1853, Sir William Wilde of Dublin introduced his famous postaural incision for suppuration of the ear with postaural abscess since then it has been widely used for the post auricular approach for tympanoplasty. [15] The incision is followed by harvesting the Temporalis Fascia Graft and elevating the Tympanomeatal Flap and visualizing the Tympanic membrane through the meatotomy incision and further elevating the annulus to examine the middle ear and placement of the underlay graft. Permeatal Approach: In this technique temporalis fascia graft is harvested through a small incision $(5 \mathrm{~mm}$ to $1 \mathrm{~cm})$ in the supra auricular region above the hairline, tympanic membrane was visualized through the External Auditory canal with the help of microscope, margins of the perforation were freshened through permeatal approach, middle ear was examined and the integrity of the ossicles assessed. Medicated gelfoam was placed in the middle ear and the harvested graft was spread over it under the freshened margins. Another layer of gelfoam was placed to secure the graft in place. Karhuketo et al., has emphasized that the method fulfills the requirements of minimally invasive surgery, and has documented better visualization and assessment of ossicles and middle ear structures.[16]

\section{Objective}

The study aimed to compare the graft acceptance and complications associated with the Permeatal Tympanoplasty with the help of microscope and traditional Postaural Underlay technique.

\section{MATERIAL AND METHODS}

A total of 74 patients between the age group 15 to 44 years who were attending the ENT OPD, suffering from Chronic Suppurative Otitis Media (CSOM) were selected on the basis of type of perforation and their workup was done to assess the candidature for tympanoplasty. The study was undertaken for one year period in which, patients attending the ENT OPD suffering from Chronic Suppurative Otitis 
Annals of International Medical and Dental Research

E-ISSN: 2395-2822 | P-ISSN: 2395-2814

Vol-8, Issue-1 | January-February 2022

DOI: $10.53339 /$ aimdr.2022.8.1.28

Page no- 205-211 | Section- Research Article (ENT)

Media (CSOM) were selected on the basis of type of perforation. Their candidature for tympanoplasty was assessed by performing the workup in the form of thorough examination of the Ear, Nose and Throat and assessment with documentation of the hearing loss was done with the help of pure tone audiometry. Affection of the mastoids were ruled out with the help of x-ray mastoid town's view. A microscopic examination of the cases was performed to confirm the findings of otoscopy and assessment of the middle ear structures. A written informed consent was sought from the patients, explaining the benefits and risk, and type of procedure to be performed. The procedure of tympanoplasty was performed by the Permeatal Tympanoplasty and traditional Postaural Underlay technique, and, the results were assessed in terms of graft take up, associated complication and improvement in hearing; the results were compared of postoperative period. Comparative analysis between the two groups were done based on using SPSS 24 software version. The level of significance was set to $5 \%$ $(\mathrm{p}<0.05)$.

\section{Inclusion criteria}

- Patients having chronic suppurative otitis media with inactive disease (6 weeks of dry ear).

- Patients of chronic suppurative otitis media with pure conductive hearing loss (assessed by puretone audiometry).

\section{Exclusion criteria}

- Patients with systemic diseases and other comorbid conditions.

- Patients with post-operative residual and reccurent perforations of tympanic membrane.

- CSOM patients with ossicular chain abnormalities.

- Patients with sensorineural hearing loss assessed with the help of Pure tone Audiometry.

- Patients with secondary cholesteatoma and granulation tissue in middle ear.

- Pregnant females.

\section{RESULTS}

A total of 74 patients were included in the study and the overall graft take was $76.92 \%$ in cases of Permeatal technique as compared to $91.66 \%$ in the case of postaural underlay technique, with a majority of the failures in the large central perforation group rendering a $p=$ 0.021 for patients operated for Large perforations, $\mathrm{p}=0.036$ for moderate perforations and $\mathrm{p}=0.476$ for small perforations. The overall $p=0.000649$ which is highly significant. On comparing the complications there were only 3 cases in Permeatal Technique compared to 16 cases in Postaural Underlay technique rendering a highly significant $\mathrm{p}$-value of 0.000000348 . There was a difference in hearing improvement with majority of the cases improving to the range of 10-22 dB in Permeatal technique compared to 08-18 dB in Postaural Underlay technique. 
Annals of International Medical and Dental Research E-ISSN: 2395-2822 | P-ISSN: 2395-2814

Vol-8, Issue-1 | January-February 2022 DOI: $10.53339 /$ aimdr.2022.8.1.28

Page no- 205-211 | Section- Research Article (ENT)

Table 1: Demonstrate and distribution of the study according to Age.

\begin{tabular}{|c|c|c|c|c|}
\hline \multirow{2}{*}{$\begin{array}{l}\text { Age } \\
\text { Distribution }\end{array}$} & \multicolumn{2}{|c|}{ Tympanoplasty (permeatal approach) } & \multicolumn{2}{|c|}{ Tympanoplasty (Post auricular approach) } \\
\hline & $\mathrm{n}=39$ & $\%$ & $\mathrm{n}=35$ & $\%$ \\
\hline $15-24$ & 3 & 6.8 & 11 & 25 \\
\hline $25-34$ & 27 & 61.4 & 14 & 31.8 \\
\hline $35-44$ & 9 & 20.5 & 10 & 22.7 \\
\hline Mean \pm SD & \multicolumn{2}{|c|}{$32.46 \pm 6.01$} & \multicolumn{2}{|c|}{$30.31 \pm 7.91$} \\
\hline Min-Max & \multicolumn{2}{|l|}{$19-44$} & \multicolumn{2}{|l|}{$17-44$} \\
\hline
\end{tabular}

Table 2: Demonstrate and distribution of the study according to sex.

\begin{tabular}{|c|c|c|c|c|}
\hline \multirow{2}{*}{$\begin{array}{l}\text { Sex } \\
\text { Distribution }\end{array}$} & \multicolumn{2}{|c|}{ Tympanoplasty (permeatal approach) } & \multicolumn{2}{|c|}{ Tympanoplasty (Post auricular approach) } \\
\hline & $\mathrm{n}=39$ & $\%$ & $\mathrm{n}=35$ & $\%$ \\
\hline Male & 25 & & 22 & 62.9 \\
\hline Female & 14 & & 13 & 37.1 \\
\hline
\end{tabular}

Table 3: Demonstrate and distribution of the study according to Complication.

\begin{tabular}{|c|c|c|c|c|}
\hline \multirow[t]{2}{*}{ Complication } & \multicolumn{2}{|c|}{$\begin{array}{l}\text { Tympanoplasty } \\
\text { approach) }\end{array}$} & \multicolumn{2}{|c|}{$\begin{array}{l}\text { Tympanoplasty (Post auricular } \\
\text { approach) }\end{array}$} \\
\hline & $\mathrm{n}=3$ & $\%$ & $\mathrm{n}=16$ & $\%$ \\
\hline $\begin{array}{l}\text { Severe sensory neural hearing } \\
\text { loss }\end{array}$ & 0 & 0.0 & 1 & 6.25 \\
\hline Mastoiditis & 0 & 0.0 & 3 & 18.75 \\
\hline Persistant otorrhoea & 1 & 33.33 & 3 & 18.75 \\
\hline Scar hypertrophy & 1 & 33.33 & 5 & 31.25 \\
\hline Wound infection & 1 & 33.33 & 4 & 25.0 \\
\hline Total & 3 & 100.0 & 16 & 100.0 \\
\hline
\end{tabular}

Table 4: Demonstrate and distribution of the study according to Surgical Outcome.

\begin{tabular}{|l|l|l|l|l|}
\hline \multirow{2}{*}{ Outcome } & \multicolumn{2}{|c|}{$\begin{array}{l}\text { Tympanoplasty } \\
\text { approach) }\end{array}$} & (permeatal & $\begin{array}{l}\text { Tympanoplasty (Post auricular } \\
\text { approach) }\end{array}$ \\
\cline { 3 - 6 } & $\mathbf{n = 3 9}$ & $\mathbf{0}$ & $\mathbf{n}=\mathbf{3 6}$ & $\mathbf{0}$ \\
\hline $\begin{array}{l}\text { Successful Tympanic } \\
\text { membrane healing }\end{array}$ & 30 & 76.92 & 33 & 91.66 \\
\hline
\end{tabular}

Table 5: Demonstrate and distribution of the hearing improvement.

\begin{tabular}{|l|l|l|}
\hline \multirow{2}{*}{} & $\begin{array}{l}\text { Tympanoplasty (permeatal } \\
\text { approach) }\end{array}$ & $\begin{array}{l}\text { Tympanoplasty (Post auricular } \\
\text { approach) }\end{array}$ \\
\cline { 2 - 3 } & range & range \\
\hline Hearing improvement & $10-22 \mathrm{~dB}$ & $08-18 \mathrm{~dB}$ \\
\hline
\end{tabular}


Annals of International Medical and Dental Research

E-ISSN: 2395-2822 | P-ISSN: 2395-2814

Vol-8, Issue-1 | January-February 2022

DOI: $10.53339 /$ aimdr.2022.8.1.28

Page no- 205-211 | Section- Research Article (ENT)

\section{DISCUSSION}

Tympanoplasty is a surgical procedure defined as reconstruction of the hearing mechanism with reconstruction of tympanic membrane. Various approaches have been described but with the advent of microscope the surgery has become quite simplified. The things to be considered which might have resulted in the difference in results between the two techniques is, first and foremost its tissue trauma which is much more in postaural approach compared to permeatal approach. Secondly handling of the tympanomeatal flap by elevating it from the bony external auditory canal also leads to edema and delayed postoperative healing which is prevented in permeatal technique. Lastly, the preservation of vascular strip comes into consideration which is not affected during the permeatal technique but there are chances of it getting damaged while raising the tympanomeatal flap, these all factors lead to more complications and affect wound healing. During the initial post-operative period the graft is held in place by the fibrin net formed by the blood clot from the freshened margins of the tympanic membrane. Later on, there is epithelization and also vascularization of the graft material. In the permeatal technique there is preservation of the blood supply of the tympanic membrane in the whole circumference which is affected in post aural technique hence, affecting the graft take up. Many studies have considered the comparison of postaural underlay grafting with permeatal technique. The advantages of the postauricular microscopic approach is bimanual surgical handling and binocular visualization, but the disadvantage of microscopy is that the field of view has to be frequently changed for better visualization of different areas which needs the patient's head to be manipulated or the microscope has to be repeatedly mobilized. Surgery, has the limitation that it is based on a two dimensional visualization of images on the monitor and because of this depth perception becomes difficult.[17] But, a full HD camera system provides much better visualization of views and has greatly minimized this drawback. Yadav et al., have emphasized that in the repair of the tympanic membrane perforation done with the help of permeatal technique there is no possibility of an iatrogenic cholesteatoma formation as compared to the conventional myringoplasty done with postaural technique.[18] Usami et al., reported on 22 myringoplasty patients treated with assistance with a follow-up time of 24.5 months. The rate of perforation closure was $81.8 \%$ and improvement in ABG after surgery was $14.8 \mathrm{~dB}$.19] Karhketo et al., reviewed the records of 29 myringoplasty patients treated with the aid of rigid endoscope with a followup time of one year. The rate of perforation closure was $80 \%$ and improvement in ABG after surgery was $7 \mathrm{~dB}$. [20] In our study, we got an overall graft take up of was $76.92 \%$ in cases of Permeatal technique as compared to $91.66 \%$ in the case of postaural underlay technique by Postaural underlay technique with majority of the patients improving to the range of $10-22$ $\mathrm{dB}$ in Permeatal technique and to the to the range of 08 - $18 \mathrm{~dB}$ by postaural Underlay technique. Raj A. emphasizes that with angled endoscope, it is possible to visualize other structures like round window niche, eustachian tube orifice, incudo-stapedial joint etc. that are difficult to observe through the operating microscope.[21] A comparative study 
Annals of International Medical and Dental Research

E-ISSN: 2395-2822 | P-ISSN: 2395-2814

Vol-8, Issue-1 | January-February 2022

DOI: $10.53339 /$ aimdr.2022.8.1.28

Page no- 205-211 | Section- Research Article (ENT)

conducted by Thirumaran NS, concluded that there is $93 \%$ graft take up rate permeatal approach compared to $91 \%$ graft take up rate by post aural approach.[22] Mohindra S. et al., did 49 cases of myringoplasty and 6 cases of ossiculoplasties through the transcanal route using microscope. The success rate regarding perforation closure was $91.5 \%$ and average air bone gap improvement was $22.24 \mathrm{~dB}$ in the myringoplasty groups.117] Ahmed ELGuindy (Tanta, Egypt) has evaluated the role of the rigid in the management of 36 cases of dry central perforation of the tympanic membrane. The graft uptake rate was 91.7 percent and air bone gap was closed to less than $10 \mathrm{~dB}$ in 83.3 percent.[23]

\section{Limitations of the Study}

The present study was conducted in a very short period due to time constraints and funding limitations. The small sample size was also a limitation of the present study.

\section{CONCLUSIONS}

The use of microscopes allows for better vision, which aids in the assessment of middle ear structures and disease. The permeatal strategy

\section{REFERENCES}

1. Singh NK, Nagpure PS, Yadav M, Chavan S. Comparative Study of Permeatal Sandwich Tympanoplasty and Postaural Underlay Technique. J Clin Diagn Res. 2016;10(4):MC01-MC4. doi:10.7860/JCDR/2016/19001.7555

2. Wullstein H. Theory and practice of tympanoplasty. Laryngoscope. 1956;66(8):1076-93. doi: 10.1288/00005537-195608000-00008.

3. House WF. Myringoplasty. AMA Arch Otolaryngol. 1960;71:399-404. doi: 10.1001/archotol.1960.03770030041009. adopts a less invasive approach to surgery, resulting in a faster recovery and less issues from tissue stress caused by the postaural underlay technique. When compared to the postaural underlay technique, Permeatal tympanoplasty has far fewer problems, which are directly related to enhanced visualization and little tissue stress. The authors want to note that using to perform the postaural technique produces superior results and allows for better explanation of the process to trainees. The authors do not simply abandon the operating microscope, as it is required when the exterior canal is narrow or excessively curved, as well as when mastoids should be evaluated.

\section{Acknowledgements}

The wide range of disciplines involved in Outcome of Tympanoplasty by Postauricular and Permeatal Approach research means that an Editors needs much assistance from referees in the evaluation of papers submitted for publication. I am very grateful to many colleagues for their thorough, helpful and usually prompt response to requests for their opinion and advice.

4. Shea JJ Jr. Vein graft closure of eardrum perforations. J Laryngol Otol. 1960;74:358-62. doi: 10.1017/s002221510005670x.

5. Kartush JM, Michaelides EM, Becvarovski Z, LaRouere MJ. Over-under tympanoplasty. Laryngoscope. 2002;112:802-07. https:/ / doi.org/10.1097/00005537-200205000-00007

6. Karlan MS. Gelatin film sandwich in tympanoplasty. Otolaryngol Head Neck Surg (1979). 1979;87(1):84-6. doi: $10.1177 / 019459987908700120$.

7. Hartwein J, Leuwer RM, Kehrl W. The total reconstruction of the tympanic membrane by the 
Annals of International Medical and Dental Research

E-ISSN: 2395-2822 | P-ISSN: 2395-2814

Vol-8, Issue-1 | January-February 2022

DOI: 10.53339/aimdr.2022.8.1.28

Page no- 205-211 | Section- Research Article (ENT)

"crowncork" technique. Am J Otolaryngol. 1992;13(3):172-5. doi: 10.1016/0196-0709(92)90118-d.

8. Schwaber MK. Postauricular undersurface tympanic membrane grafting: some modifications of the "swinging door" technique. Otolaryngol Head Neck Surg. 1986;95(2):182-7. doi: 10.1177/019459988609500209.

9. Escudero LH, Castro AO, Drumond M, Porto SP, Bozinis DG, Penna AF, et al. Argon laser in human tympanoplasty. Arch Otolaryngol. 1979;105(5):252-3. doi: 10.1001/archotol.1979.00790170022005.

10. Williams JD. Microclip application in tympanoplasty. Ann Otol Rhinol Laryngol. 1977;86(2 pt. 1):223-6. doi: 10.1177/000348947708600214.

11.Goodman WS, Wallace IR. Tympanoplasty--25 years later. J Otolaryngol. 1980;9(2):155-64.

12. Albera R, Ferrero V, Canale G. Annular wedge tympanoplasty: una variante della miringoplastica overlay Annular wedge tympanoplasty: a variation of overlay myringoplasty. Acta Otorhinolaryngol Ital. 1997;17(1):15-21.

13. Lee HY, Auo HJ, Kang JM. Loop overlay tympanoplasty for anterior or subtotal perforations. Auris Nasus Larynx. 2010;37(2):162-6. doi: 10.1016/j.anl.2009.06.002.

14. Kartush JM. Tympanic membrane Patcher: a new device to close tympanic membrane perforations in an office setting. Am J Otol. 2000;21(5):615-20.

15. Practical Observations on Aural Surgery, and the Nature and Treatment of Diseases of the Ear. Glasgow Med J. 1854;2(6):213-224.

16. Karhuketo TS, Ilomäki JH, Puhakka HJ. Tympanoscope-assisted myringoplasty. ORL J
Otorhinolaryngol Relat Spec. 2001;63(6):353-7; discussion 358. doi: 10.1159/000055773.

17. Mohindra S, Panda NK. Ear surgery without microscope; is it possible. Indian J Otolaryngol Head Neck Surg. 2010;62(2):138-41. doi: 10.1007/s12070010-0033-5.

18. Yadav SP, Aggarwal N, Julaha M, Goel A. Endoscope-assisted myringoplasty. Singapore Med J. 2009;50(5):510-2.

19. Usami S, Iijima N, Fujita S, Takumi Y. Endoscopicassisted myringoplasty. ORL J Otorhinolaryngol Relat Spec. 2001;63(5):287-90. doi: 10.1159/000055759.

20. Karhuketo TS, Ilomäki JH, Puhakka HJ. Tympanoscope-assisted myringoplasty. ORL J Otorhinolaryngol Relat Spec. 2001;63(6):353-7. doi: 10.1159/000055773.

21. Raj A, Meher R. Endoscopic transcanal myringoplasty-A study. Indian J Otolaryngol Head Neck Surg. 2001;53(1):47-9. doi: 10.1007/BF02910979.

22. Jyothi AC, Shrikrishna BH, Kulkarni NH, Kumar A. Endoscopic Myringoplasty Versus Microscopic Myringoplasty in Tubotympanic CSOM: A Comparative Study of 120 Cases. Indian J Otolaryngol Head Neck Surg. 2017;69(3):357-362. doi: 10.1007/s12070-017-1147-9.

23.el-Guindy A. Endoscopic transcanal myringoplasty. J Laryngol Otol. 1992;106(6):493-5. doi: $10.1017 / \mathrm{s} 0022215100119966$.

Source of Support: Nil, Conflict of Interest: None declared 